\title{
THE ROLE OF TERTIARY EDUCATION IN CAREER AND LIFE-LONG LEARNING AMONG DAY-TIME STUDENTS (BASED ON EMPIRICAL FINDINGS)
}

\author{
Csilla Czeglédi \\ czegledi.csilla@gtk.szie.hu \\ Szent István University, Hungary \\ Tímea Juhász \\ juhasz.timi@hotmail.com \\ Szent István University, Hungary
}

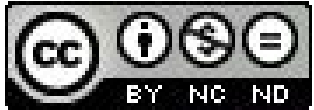

\begin{abstract}
There is an increased demand for education in our society. The expectations of employers and the economy in general have also changed; knowledge is fast becoming the driving force behind labour market competitiveness. Seeing these tendencies, we had to ask ourselves how the most involved group, the students see their situation. How do they see the role of education in their career paths as well as in life-long learning? We conducted our research in this field in the second half of last year. In this essay, we are publishing some partial results of that research in order to prove the hypothesis made during our studies.
\end{abstract}

Key words: career, life-long learning, choosing school, motivational tools.

\section{INTRODUCING THE PROFESSIONAL LITERATURE}

The professional literature has been mostly provided by writings and studies about the changes within the Hungarian tertiary education, as well as the altered role of learning. These changes greatly influence the phenomenon which is targeted by our research.

In Hungary, the tertiary educational system used to be characterized by a dual training and institutional system at the time of the change in regime in 1989. By joining the European Union, we also had to join the European tertiary educational region, and for this reason, a new linear training system was introduced in September 2006; this involved the $\mathrm{BA} / \mathrm{BsC}$ basic courses as well as the $\mathrm{MA} / \mathrm{MsC}$ master and doctoral courses (Hajós, Csehné, \& Czeglédi, 2012, p. 115). The levels are built upon each other in a linear manner, and each of them allows entry to the next level, but not to all courses and institutions of the next level. However, the Bologna Process - the aims and goals of which have been modified and enriched on the way - is not only about the modification of the training structure, but also about allowing easier access and harmonized tertiary educational systems. Realizing these aims would create a unified European educational region (Hrubos, 2003).

The legal background of further modification was created by the new tertiary educational law. The work program created for this period of time is called Oktatás 
és képzés, 2010 (Education and Training 2010), which also drew a common tertiary education policy in accordance with the Lisbon Strategy.

The newest EU guidelines are also set in the frame "Education and Training $2010 "$, which expires in 2020. In some areas such as the creation of knowledge-based society, there have been missing elements, and these goals are going to receive greater emphasis for the next time period. It sets four strategic objectives:

- realizing life-long learning and mobility,

- improving the effectiveness and quality of education and training,

- $\quad$ enhancing proper social cohesion and active civic involvement,

- $\quad$ advancing creativity and innovation - including entrepreneurial activities on all level of education and training (Education and Training, 2020) ${ }^{11}$.

As we can see from the list, learning is not restricted to tertiary studies; the globalization of economy and various social changes have led to the phenomenon of life-long learning. In order to retain competitiveness, to develop continuously and to avoid poverty and social failure, we must also invest in education and training in a continuous manner. The labour market justifies the importance of school education from various aspects:

On the one hand, if we consider the rates of unemployment in terms of school graduation, we can clearly see that there are less unemployed among the people with university or college degree than among those with at most a secondary qualification. The rate of unemployment in 2011 was 3-5\% among people with diplomas (college: 5.1\%, university: $3.4 \%$ ), while the same rate was $9-10 \%$ among those with secondary qualifications.

On the other hand, there has been a marked increase in the number of people with tertiary degrees in the last decade. If more people have higher degrees, it is no longer considered to be an advantage in the labour market, and we believe this is the reason why people decide to continue studying even after their qualification.

Choosing the right school and the right area of expertise is quickly becoming a crucial factor as the returns in education can be measured in the labour market. The newest results in this field were published by Hungarian career path observing studies $^{12}$. The studies revealed that most young people choose learning to avoid unemployment, and higher salaries are only a secondary motivating factor to them. The education level of the parent was also an important factor in continuing to study. When choosing an institution or a course, the most important factor was the prestige of the school and the degree of appeal of the course itself.

This assessment system allowed us to examine the labour market allocation of fresh graduates. Demand has been lowered in the past few years, as opposed to offer, which has increased and diversified. In spite of all this, recession and slow economic growth means that tertiary degrees are more valuable than ever before. Although a tertiary degree is not an automatic success in the labour market, people

11 The Bologna World Forum was organized within the Bologna ministerial meeting held in Budapest and Vienna in March 2010.

12 Tertiary Degree Career Path Observer System DPR (Diplomás Pályakövető Rendszer), one of the highlighted component of Project TÁMOP 4.1.3. 
with some form of diploma are still at a more advantageous position than those without one. A survey indicates that firms like employing fresh graduates with a degree because they are more flexible, more creative and demand less payment. Another important factor in a career path is language knowledge. KSH shows in its publication that there are differences in quality and structure between individual training types; this notion has been supported by other, similar, researches (Várhal$\mathrm{mi}$, 2012). This inevitably involves labour-market effects as well.

\section{RESEARCH AND HYPOTHESIS}

The professional literature clearly indicates that this topic has become a timely social studies area in the past few years. We also launched our own studies in the second half of last year to find out how Hungarian students currently active in the daytime tertiary educational system think of their later career, family life and the harmonization of these important fields of life. An important part of our research was the question of choosing tertiary education form, the reasons for such a choice and the role of training in our career and life-long learning. In the following essay, we present our experience gained in the last two fields of research, based on our own findings. We are going to examine the validity of our hypothesis, primarily according to the quantitative results. Out hypothesis was the following:

\section{HYPOTHESIS}

The students involved in our research claim that the Hungarian tertiary education provides them with suitable theoretical and practical basis for their further career, for better chances in the labour market as well as the incentive for life-long learning, which also supports their active labour market participation.

\section{SAMPLE}

As we have already mentioned, we launched our research in the autumn of 2012, first in a qualitative form. We later used the results of this first research to initiate a quantitative research among the various Hungarian tertiary educational institutions.

Our qualitative research consisted of in-depth interviews, during which, we questioned 19 students currently participating in daytime education about their plan for their family life and career as well as the role of tertiary education in these plans. We were able to draw the following conclusions:

Approximately half of those taking part in the research claimed that a diploma is an unavoidable factor in their later successes, and it is by no means the same whether somebody studies at a given institution or not. Several of them believed that while a diploma used to represent an automatic job in the labour market, it is no longer a guarantee for active labour market participation. This view may be justified by the fact that there is a shortage of workers in Hungary today even in fields which traditionally require only secondary qualification (for example: electrician, painter, shop assistant, cook etc.). 
At the same time, the students answering our questions agreed that tertiary educational institutions typically provide theoretical knowledge, not the ability to use that knowledge in a practical manner; the students cannot, or cannot fully acquire practical skills, although having experience is a necessary requirement in getting most of the available jobs.

The students we asked would primarily have liked to work after graduation, and they did not necessarily imagine their future career in Hungary. At the same time, several of them believed that successful graduation is not enough for a successful career, and so they were planning to start or continue studying even after finishing school. Students saw life-long learning as a kind of requirement for their career, but they did not think that it would automatically lead to labour market success. In order to be successful, the diploma has to be issued by the right institution, you have to work in the right place, you need connections, you need to be achievement-oriented, you need to represent your own requirements, and, finally, gender is still an issue today.

The results of the qualitative research showed that this question is complicated, and we could use the data collected from the interviews to make a new questionnaire and make a quantitative research. Our research concentrated on several key areas.

The first group of questions concentrated mainly on the reasons for choosing schools: we wanted to know the factors which influence the students in choosing a particular educational institution.

The next part of the questionnaire asked about the career expectations of the students: here, we wanted to find out how tertiary studies influence career planning, and how this provides a basis for life-long learning.

In the final part of the questionnaire we examined the problems of family planning and the harmonization of work and family life from the pint of view of the students: this way, we could find out about their opinions before they would become active job seekers.

Our questionnaire consisted of 5 open and 5 closed questions, which were built upon nominal, ordinal and metric (typically the 5 point Likert) scales.

Our respondents were Hungarian university students currently engaging in daytime courses. The students could fill in the questionnaire through the Internet on a voluntary basis. We received 483 questionnaires, 7 of which were not valid, and, consequently, left out of the research.

All in all, 476 questionnaires have been analysed during our research. We know that the results cannot be considered representative, but we believe that we are nevertheless able to get a general picture of the current situation.

Our methods of analysis consisted of both multiple and one-variable methods, and so they contained, among others, cross-table analyses, one-way ANOVA and logistic regression.

\section{RESULTS}

We are beginning the presentation of the results by specifying the samples:

Our questionnaire was filled in by 148 men and 328 women, who belonged to the age categories between of 18 and 41 years. 
Regarding their place of residence, most people came from Central Hungary, the most developed region of the country. The regional distribution showed that $23.1 \%$ lived in Northern Hungary, $7.6 \%$ in the Southern Great Plains, $4.4 \%$ in Central Transdanubia and Western Transdanubia each and, finally, 1.1\% came from Southern Transdanubia.

$20 \%$ of the students were freshmen, $44.5 \%$ were in their second, $22.1 \%$ in their third, $9.4 \%$ in their fourth and, finally, $4 \%$ of them were in their fifth year of studies.

As regards their studies, the majority of them $(32.8 \%)$ were studying social sciences, $14.7 \%$ were engineering students, $8.4 \%$ studied humanities, $3.2 \%$ were at pedagogical courses, $1.7 \%$ studied medical sciences and art respectively, while the remaining $31.1 \%$ of the students were actively studying somewhere else.

The respondents listed several factors when choosing their courses; these factors already included career considerations. Approximately $18.9 \%$ of the students mentioned that they had decided on their course because they believed they would get a job easier in their chosen profession. Another 20.4\% thought that they would earn good money in that particular area after graduation.

$34.7 \%$ of the students in our research would be the first person with a tertiary degree in their family, while $65.3 \%$ had at least one close relative with such a qualification. It was interesting to see that the chance of having a diploma was modified by the factor of whether someone else from the family was working in that professional field. Our logistic regression researches showed that in the case of a very simple significant model, there is a 1.327 higher chance of somebody not being the first one with a degree if another family member works in the student's chosen area. (Wald-statistics: 16.020, df: 1, sign.: .000 p<0.05, $\operatorname{Exp}(B): 1.327)$.

The fact is, whatever the motivation for students to engage in tertiary education, every third of them believed that they would not need specifically a college or university degree to realize their ambition. In this respect, there is no significant difference between genders (Pearson Chi-square: $1.526 \mathrm{df} 1$ sign.: .217 p>0.05); 31.4\% of women and $37.2 \%$ of men were thinking this way.

However, there was a difference in this respect between those students with another relative with a degree in their family and those without one (Pearson Chi-square: $4.379 \mathrm{df}: 1$ sign.: $.036 \mathrm{p}<0.05)$. When there was somebody in their family with a tertiary degree, approximately $30 \%$ of the students believed that they needed no degree for their career themselves, while the same percentage among those students without such a relative was almost $40 \%$.

We asked the students what their plans were after graduation. Most of them mentioned working in the country (60.5\% of all respondents), while their second answer was their active participation in the labour market, but abroad. The willingness to migrate for Hungarians, more particularly, the Hungarian youth, was also examined by Tárki (2012). Their research showed last year that the migration willingness of this age group, especially those under 30 is higher than the average (which is 19\%). Almost half of those people between 18 and 29 think of working or living abroad. In our research, about $35.3 \%$ of the young people said they would have liked to try working outside the country. In the following chart, we are presenting the frequency of different plans based on the answers we received: 
Table 1. Chart 1: Plans Following Graduation.

\begin{tabular}{|l|l|}
\hline Plans Following Graduation & $\%$ \\
\hline Working in this field in Hungary & 31 \\
\hline Working in this field abroad & 18 \\
\hline Learning languages abroad & 12 \\
\hline Getting a new degree in Hungary & 11 \\
\hline Learning a new language in Hungary & 9 \\
\hline Establishing a family & 9 \\
\hline Learning a different profession in Hungary & 3 \\
\hline Getting a new degree abroad & 3 \\
\hline Learning a different profession abroad & 1 \\
\hline I have no plan & 1 \\
\hline Others & 1 \\
\hline
\end{tabular}

Source: Own Chart.

Our in-depth interviews already indicated that the first step of young people towards a successful career was to get the right job. At the same time, we also saw that the most important motivating factors were the salary and the organizational culture, and the position they would take was almost of no importance to our respondents. Our quantitative examinations resulted in similar answers. The respondents were mostly motivated by financial reasons when looking for a job, which was followed by the atmosphere in the workplace, and the question of professional career within the company only came afterwards.

We examined whether we could find any significant difference between working abroad or in the country. We found that the opinion about working in Hungary was seen differently by girls and boys (Pearson Chi-square: $7.427 \mathrm{df}$ : 1 sign.: .006 p<0.05). While $69.6 \%$ of the men thought that they would like to work in Hungary, the same result among women was $56.4 \%$. regarding working abroad, there was no significant difference among the two genders (Pearson Chi-square: $1.427 \mathrm{df}$ : 1 sign.: . $232 \mathrm{p}>0.05 .33 .5 \%$ of all women and $39.2 \%$ of all men would have worked abroad if the opportunity had presented itself).

It was interesting to see that almost every fifth student would have liked to get an additional degree, and about $18.5 \%$ would also have liked to learn a new language in Hungary after graduation, while $5.7 \%$ mentioned that they would study abroad for a new degree, and $23.3 \%$ would learn the new language outside the country. It is no wonder that learning a language is important for the students, as they thought this was one of the most important skills expected from them by their future employees.

Although the Hungarian tertiary institutions all require their students to acquire a language before graduation, the practice shows that although the young people typically speak English and German, relatively few of them speak it well (that is, at advanced level, see KSH 2011). At the same time, employers often require their employees to speak several languages, and the 2011 survey of KSH showed that only $29.5 \%$ of those respondents between 15 and 29 knew two languages, while only 3.2\% of them actually spoke three.

The young respondents mentioned language skills and professional experience as an important requirement, although our in-depth interviews indicated that the various institutions could not or could not completely integrate these elements into their educational curriculum. The following chart shows the expectations students think employers have towards their new employees: 
Table 2. Chart 2: Expectations of Employers.

\begin{tabular}{|l|l|}
\hline Expectations & $\%$ \\
\hline Language knowledge & 25 \\
\hline Professional experience & 25 \\
\hline Diploma & 13 \\
\hline Professional knowledge & 13 \\
\hline High level of communication & 13 \\
\hline IT knowledge & 6 \\
\hline Independence (marital status) & 4 \\
\hline High level of emotional intelligence & 1 \\
\hline Others & 0 \\
\hline No expectation & 0 \\
\hline
\end{tabular}

Source: Own Chart.

We can see that young people think employers are less likely to appreciate professional knowledge and diploma than professional experience and language knowledge which could be actively used in their work. However, students also found that the various professional and language knowledge elements had to be developed continuously, and, consequently, most of the respondents agreed with continuous training and knowledge development even outside work. Regarding this idea, we made statements on a five-point Likert scale, which were basically all about training and knowledge development following the students' tertiary education. The students had to grade these statements on a 5-point scale: 5 meant complete agreement, 1 meant complete disagreement. We collected the results of some of the statements in the following chart:

Table 3. Chart 3: Opinions Regarding Post-University Professional Knowledge Development.

\begin{tabular}{|l|l|l|l|l|}
\hline \multicolumn{1}{|c|}{ Claims } & $\mathrm{N}$ & Mean & $\begin{array}{c}\text { Std. De- } \\
\text { viation }\end{array}$ & $\begin{array}{l}\text { Std. } \\
\text { Error }\end{array}$ \\
\hline $\begin{array}{l}\text { After acquiring my first diploma, I am planning to get } \\
\text { another one. }\end{array}$ & 476 & 3.13 & 1.384 & .063 \\
\hline People have to train themselves even besides work. & 476 & 4.32 & .867 & .040 \\
\hline $\begin{array}{l}\text { After acquiring my diploma, I would like to learn another } \\
\text { language. }\end{array}$ & 476 & 3.96 & 1.157 & .053 \\
\hline $\begin{array}{l}\text { I am only going to attend further courses if they are or- } \\
\text { ganized by my company. }\end{array}$ & 476 & 2.45 & 1.101 & .050 \\
\hline $\begin{array}{l}\text { I am willing to invest even money into improving on the } \\
\text { skills necessary for my work. }\end{array}$ & 476 & 3.78 & .979 & .045 \\
\hline $\begin{array}{l}\text { I find it important not only to take part in the courses } \\
\text { provided by my company, but also in courses not relevant } \\
\text { to my job. }\end{array}$ & 476 & 3.83 & .986 & .045 \\
\hline $\begin{array}{l}\text { Professional knowledge is only a means to success if it is } \\
\text { combined with practical experience. }\end{array}$ & 476 & 4.42 & .803 & .037 \\
\hline
\end{tabular}

Source: Own Chart. 
We can see from the results of the chart that for today's students learning and self-training does not end at graduation; on the contrary, life-long learning is an inevitable part of their career path, and it is indispensable for their active labour market presence.

We examined in our research whether there was any significant difference between men and women regarding the above statements. The ANOVA-test showed that there was such a difference in two cases. One of the two claims said "people should train themselves continuously even outside work" (Levene-test: 0.352, sign.: .553 p >0.05, F: 6.532 sign.: .011 p<0.05): the average was 4.39 among women and 4.17 among men, which means female respondents could accept this statement more.

There was also a significant difference in the case of another statement: "I am only going to attend further courses if they are organized by my company" (Levene-test: 0.621, sign.: .431 p>0.05, F: 5.161 sign.: .024 p<0.05). Here, women disagreed more than men (mean: 2.38 and mean: 2.62 respectively).

Finally, perhaps it is no coincidence that $54.2 \%$ of the responding students thought they did not meet the requirements of their future employers. There was no significant difference between the two genders in this respect (Pearson Chi-square: $0.059 \mathrm{df:} 1$ sign.: .809 p $>0.05$ ): $54.6 \%$ of all women and $53.4 \%$ of all men believed so. Our research also investigated how students studying at different courses feel their knowledge is up to the requirements of the labour market. There was no significant difference among students studying at various courses either (Pearson Chi-square: 5.218 df: 7 sign.: .633 p>0.05), which means most students do not feel ready for labour market demands. Also, the respondents felt that the career of a young worker today is influenced by how connected they are and how much professional experience they have; professional knowledge is a low priority to them.

\section{CONCLUSION}

In order to prove the validity of the hypothesis made in this essay, we have presented the quantitative and qualitative results of some of our researches done this year.

Based on the published results, we can say that our hypothesis was only partially valid.

The students who participated in our research are actively studying at some daytime course, and they believe that the Hungarian institutions typically provide theoretical professional knowledge, even though they would need practical knowledge as well. The Bologna educational system is supposed to meet the demand of the labour market through the $\mathrm{BsC}-\mathrm{MsC}$ levels; the $\mathrm{BsC}$ level is more practical, while the $\mathrm{MsC}$ should provide theoretical knowledge. We can only conclude that this has not been effectively implemented. The figures of the labour market show that it is worth learning. The students share this opinion, and they typically plan to acquire several degrees, even through self-studies. Life-long learning is no longer a meaningless idea: continuous learning and training has become part of the career path. In our speeding world, this is a requirement for success and compatibility. At the same time, universities and colleges provide a good basis and a motivational factor for young people, which in turn makes them improve and develop their knowledge and skills throughout their lives. 


\section{REFERENCES}

Barakonyi, K. (2004). Rendszerváltás a felsőoktatásban Bologna-folyamat, modernizáció [Change of Regime in Tertiary Education: the Bologna Process and Modernization]. Budapest: Akadémiai Kiadó.

Csúcson a migrációt tervezók aránya [The migration planers' rate is on top]. (2012). Retrieved from http:/ / www.tarki.hu/hu/news/2012/kitekint/20120523_migracio.html.

Fábri, I. (2010). Egyetemi és főiskolai hallgatók elhelyezkedési motivációi [Job-Seeking University and College Students and their Motivations]. Educatio, 2010/2, 241-250.

Farkas, A., Kollár, Cs, \& Laurinyecz, Á. (Eds.). A filozófia párbeszéde a tudományokkal [A Conversation Between Philosophy and Sciences]. Budapest: Protokollár Tanácsadó Iroda.

Garai, O., Horváth, T., Kiss, L., Szép, L., \& Veroszta, Zs (Eds.). Diplomás pályakövetés IV. Frissdiplomások [The Latest Professional Classes]. Budapest: Educatio Társadalmi Szolgáltató Nonprofit Ltd.

Györgyi, Z. (2010). Munkaerő-piaci esélyek, munkaerő-piaci stratégiák [Labour-Market Chances, Labour Market Strategies]. Retrieved from http://www.felvi.hu/pub_bin/dload/DPR/dprfuzet4/ Pages37_58_Gyorgyi.pdf.

Hajdú, M. (2012). Érdemes diplomát szerezni Magyarországon vagy munkanélküliség vár a pályakezdő diplomásokra? Elemzés a diplomások munkaerö-piaci helyzetéról [Is It Worth Acquiring a Diploma in Hungary or Are New Graduates Facing Unemployment? A Labour-Market Analysis of Graduates]. Retrieved from http://www.gvi.hu/data/papers/diploma_2012_ksh_diplomas_120801.pdf.

Hajós, L., Csehné, P. I., \& Czeglédi, Cs. (2012). A közgazdasági képzés történeti fejlődése hazánkban [The Historical Development of Economic Education in Hungary]. In.: A. Farkas, Cs. Kollár, \& Á. Laurinyecz, (Eds.). A filozófia párbeszéde a tudományokkal [A Conversation Between Philosophy and Sciences] (pp. 115-128). Budapest: Protokollár Tanácsadó Iroda.

Hrubos, I. (2006). A 21. század egyeteme [The University of the 21th Century]. Educatio. Vol 15(4), 665-683.

Hrubos, I., Szentannai Á., \& Veroszta Zs. (2003). A „bolognai folyamat”. Az Európai Felsőoktatási Térség gondolatának megjelenése és a megvalósitás esélyei [The "Bologna Process". The Outline and Further Chances of the European Tertiary Educational Region]. Budapest: Oktatáskutató Intézet - Új Mandátum.

Jancsák, Cs. (Eds.). Pillanatfelvételek a Kárpát-medencei ifjúságról [Segments of the Carpatian Basin Youth] (pp.13-27). Szeged: Belvedere Kiadó.

Kasza, G. (2010). Helyzetkép a nemzetközi hallgatói mobilitásról [The Situation of International Student Mobility]. In: O. Garai, T. Horváth, L. Kiss, L. Szép, \& Zs.Veroszta (Eds.), Diplomás pályakövetés IV. Frissdiplomások [The Latest Professional Classes], (pp. 177-192). Budapest: Educatio Társadalmi Szolgáltató Nonprofit Ltd.

KSH (2011). A fiatalok munkaeró-piaci helyzete [The Labour Market Chances of Young People. Based on the basic survey and supplemented by the results of the fourth quarterly supplementary survey of 2010]. Retrieved from http://www.ksh.hu/docs/hun/xftp/idoszaki/pdf/ifjusag_munkaero_ piac.pdf.

Oktatás és képzés 2020 [Education and Training 2020]. Retrieved April 28, 2013, from http:/ / europa.eu/ legislation_summaries/education_training_youth/general_framework/ef0016_hu.html.

Szemerszki, M. (2010). Hallgatók az átalakuló felsőoktatásban [Students in the Changing Tertiary System]. In: Cs. Jancsák (Eds.), Pillanatfelvételek a Kárpát-medencei ifjúságról [Segments of the Carpatian Basin Youth] (pp.13-27). Szeged: Belvedere Kiadó.

Várhalmi, Z. \& Tóth I. (2012). Diplomás pályakezdók a versenyszektorban [Fresh Graduates in the Competitive Sectors]. Retrieved from http://www.gvi.hu/data/papers/diploma_2011_osszefoglalo_120130_.pdf. 